\title{
THE ROLE OF SOCIAL CAPITAL AND INTERPERSONAL RELATIONS IN THE ALLEVIATION OF EXTREME POVERTY AND SPATIAL SEGREGATION OF ROMANI PEOPLE IN SZEGED
}

\author{
Boglárka MÉREINÉ BERKI*, György MÁLOVICS*, Janka TÓTH**, \\ Remus CRETAN*** \\ *University of Szeged, Hungary; **Independent researcher, Szeged, Hungary; \\ ${ }^{* * *}$ West University of Timişoara, Romania
}

\begin{abstract}
Even more emphasis is set on social capital in understanding, analyzing and planning poverty alleviation measures and policies. However, our understanding of the role of social capital in alleviating extreme poverty, enhancing social mobility and fighting spatial segregation, is still inadequate. Within the present study, we aim to examine and understand (1) the mechanisms that relate to social capital in the case of the segregated urban underclass and (2) the potential interventions for poverty alleviation concerning social capital. In order to examine the dynamics of poverty alleviation measures related to social capital, special attention is paid to the experiences of a cooperative network aimed at creating artificial bridging capital through the introduction of interpersonal relations locally between the middle class and underclass, the patronage network, which was initiated within a broader participatory action research (PAR) process. Our results show that bonding ties and related specific norms as tools for everyday survival easily overwrite system integration efforts for poverty alleviation and social mobility with long-term and uncertain benefits for the segregated urban underclass. In order to overcome this failure, social institutions should place more emphasis on developing meaningful interpersonal relations with the underclass since these might be able to provide personalized help, facilitation, and approximation of perspectives - all being vital for poverty alleviation and social mobility.
\end{abstract}

Key Words: poverty alleviation, bridging social capital, segregation, urban underclass, Romani communities, Szeged.

\section{Introduction}

Social capital is a less concrete and measurable type of capital compared to human or physical capital. Therefore, its analysis and conscious application in development policies is yet immature. However, it is even more often seen as a missing link which is able to serve as a tool for strengthening or weakening the effects of human and physical capital and for understanding and redressing deeper structural problems (Woolcock and Narayan 2000).

As a rather relevant factor in understanding the problems of marginalized populations and the frequent failure of anti-poverty policies, social capital is able to both open up spaces for social mobility and poverty alleviation and to contribute to the conservation of given social structures for generations. Although the significance of social capital concerning poverty alleviation and social mobility has been recognized in the special literature for decades (Granovetter 1973, Putnam 1993, Woolcock and Narayan 2000), this is still neglected in the Hungarian development policy (Méreiné Berki et al. 2017).

Despite some numerous efforts on detailed typology, social capital does not have any unified conceptual definition (Esser 2008, Csizmadia 2015). In general, social capital is understood as a non-material resource appearing as connections between individuals and formal and informal social groups, which interweaves the political and economic life of societies (Hanifan 1916, Ben 
-Porath 1980, Bourdieu 1986, Coleman 1998). Social capital plays an important role in the economic research and especially in strategic planning and development (Füzér et al. 2005, Savanya 2013, Schvab et al. 2015, Schvab 2016). International development organizations (e.g. the World Bank, OECD and UN) put an outstanding emphasis on social capital in relation to international development projects (Füzér et al. 2005). Social capital has also been becoming an even more influential concept in the Hungarian development policy planning - it is included in the Hungarian City Development Handbook (NFGM 2012), which serves as the main background document of the major Hungarian local development planning documents of Urban Development Concepts (UDP) and Integrated Urban Development Strategies (IUDS).

Social capital is able to have an influence on many other forms of capital. Its neglect might lead to impolitic development interventions (Méreiné Berki et al. 2017), as social capital is the key for the operability of democracy (Putnam 1995). Moreover, social capital might influence the situation of individuals, groups and settlements. It influences the opportunities of individuals to participate in development processes. It might play a role in the coming into being of formal and informal institutions and might be a key factor in different bottom-up initiatives. It might play a bridging but also a bonding role: it might encourage or set back the social integration of individuals and groups or the social cohesion in general and it can even give a new meaning to these notions (Lockwood 1964, Putnam 1995, Castel 2000, Woolcock and Narayan 2000). Therefore, social capital is extremely relevant in understanding extreme poverty and segregation. In order to examine the role of social capital in the alleviation of segregation and extreme poverty, we first examine how notions of solidarity and integration relate to the concept of social capital.

The notion of "integration" frequently appears as an unquestioned and undebated goal of poverty alleviation efforts. Examples are the earlier introduced UDCs and IUDSs of major Hungarian cities, the included local antisegregation plans, and Hungarian local development policies in general (Méreiné Berki et al. 2017). However, the notion of integration is by far not a simple one. Questions such as: "Why and with whom do we formulate connections?" and "What inward and outward forces keep certain communities together?", and the meaning of social integration in relation to these is by far not evident. Durkheim (1893) aimed to address these questions by distinguishing two types of social solidarity. While mechanical solidarity is based on the feeling of belonging together because of similarity (we belong to the same family or ethnic group, we have a similar social status, we do the same work etc.), organic solidarity is based on differences: despite our differences we still have to cooperate with each other (most of all because of the division of work).

Castel (2000) distinguishes three degrees on the scale of integration. Lack of integration means "disaffiliation", partial presence of integration means belonging to "disaffiliation zone", while full integration means belonging to the "integration zone". Integration is realized through performance in three dimensions: work, community embeddedness, and culture. These function in different areas such as our place in the division of work, family or school, and they are strongly related to the social capital acquired at these areas. But, Lockwood (1964) distinguishes the system integration from the social integration. While system integration is realized through participation in social institutions (most of all the division of labor), social integration means belonging to smaller communities including networks of relatives, friends or neighbors functioning as the "natural" milieu and support for individuals (Archer 1996). Social integration might be especially strong in the case of the segregated and marginalized extremely poor, mainly in the Central and Eastern European context (Creţan and Turnock 2008, Farkas 2012).

According to the social network theory of Granovetter (1973), societies are interweaved by strong and weak ties. Strong ties are usually closed and appear within communities. These are potentially able to provide security and resources for the members of the given group. Weak 
ties span social groups, and these are the ones which are able to significantly contribute to upward social mobility and social integration (understood here as system integration) through connecting otherwise disconnected social groups.

The earlier interpretations of solidarity, integration and social ties show an eye-catching parallel with those social capital theories which aim to classify social capital by understanding and interpreting the direction and strength of social connections (Putnam 1993, Gittel and Vidal 1998, Woolcock and Narayan 2000). These theories distinguish either two or three types of social capital.

Bonding social capital is based on inner ties (Durkheim 1893) and most of all on mechanical solidarity (Granovetter 1973). Bonding connections are based on trust, solidarity and reciprocity (Messing and Molnár 2011). For the extremely poor, these closed and homogenous relations contribute to the everyday survival and they function as resources, on the one hand, but they reduce the opportunities to break out from poverty and they might be of a limiting nature, on the other hand, since group solidarity is often based on the opposition to the mainstream society (Fehér and Virág 2014). Therefore, these factors are also able to contribute to the conservation of extreme poverty for generations.

Mobility among social groups and system integration is supported by bridging and linking social capital, which are most of all based on weak ties (Putnam 1993, Woolcock and Narayan 2000, Messing and Molnár 2011, Füzér 2015). Bridging social capital means weak ties that span different social groups and thus provide access to the resources of other social groups. This type of capital functions through farther friends and acquaintances. Linking social capital "describes the ability of groups to engage with external agencies, either to influence their policies or to draw on useful resources" (Pretty 2003: 1913). Therefore, linking capital is related to formal organizations (institutions) having relative power over the given social group, including the providing of access to services or jobs (Hawkins and Maurer 2010, Messing and Molnár 2011). For the underclass urban Hungarian Roma (i.e. low-income families who live in segregates as ethnically homogenous ghettos and who are often referred to through stigmatization, and generally regarded as 'outsiders' by the majority population and constitute the underclass - Massey and Denton 1993, Ladányi and Szelényi 2004), such institutions might include non-governmental organizations (NGOs), local Roma minority self-governments (LRMSGs), the local municipality and representatives, the family support office, etc. These connections are also able to contribute to system integration since linking capital might contribute to openness and awareness among social groups and it encourages the flow of information and resources. Thus, linking capital is able to contribute to organic solidarity (Durkheim 1893).

By outlining the earlier duality, we do not want to suggest that system integration should be the major goal of poverty alleviation. Pure system integration is indeed a rather questionable goal both morally and practically in the case where it aims to overcome socially integrated life worlds: in such a case, system integration might not be a legitimate position (process) for the affected. "Integration" should be understood as cultural pluralism and based on the matching of socially integrated life worlds and system integration (Farkas 2012).

Social capital, solidarity and integration strongly influence and could be influenced by urban segregation which is a spatial appearance of social distances and inequalities among different social groups (Ladányi 2007). According to the Hungarian Central Statistical Office, segregated areas (often whole villages) can be determined objectively by using quantitative indicators related to education and unemployment (NFGM 2012).

The international scientific literature uses the notion of slum or ghetto instead of segregate to describe the spatial concentration of poverty. According to Wacquant (2012), the spatial 
concentration of poverty and ethnicity are not the only characteristics of ghettos. In addition to these, (1) ghettos are spatially sharply separated from the other parts of the given settlement; (2) people living here are stigmatized by the majority; (3) living in a ghetto is not a decision based on free will, but people move into ghettos because of necessity; and (4) ghettos are characterized by a distinct and duplicative set of institutions. Since this definition of a ghetto (Wacquant 2012) is far more sophisticated compared to the official Hungarian interpretation of a "segregate" described earlier (NFGM 2012) and it fits to those places and communities which are in the focus of the present study, we will further use the expression "segregate" which is very close to the Wacquant's (2012) definition of a ghetto.

Thus, although it is clear that social capital, solidarity, integration and urban segregation are strongly interrelated concepts, there is a research gap concerning their relationship in relation to segregated urban Roma communities in the international scientific literature. Much has been written earlier about social capital and its relationship to poverty (Woolcock and Narayan 2000). Recently, the relationship between social capital and poverty has been empirically examined most of all in the developing contexts of China (Zhang et al. 2017), South-Africa (Baiyegunhi 2014), Buthan (Tenzin et al. 2015), India (Das 2004) and Bangladesh (Khatun and Hasan 2015) but also in the developed countries of Italy (Andriani and Karyampas 2015), USA (Greenbaum et al. 2008, Hawkins and Maurer 2010) and New Zealand (Boon and Farnsworth 2011). Recent literature on the Roma extends to diverse topics, including: the effects of certain EU policies on the Roma (Van Baar 2015); the contradictions of "civilizing" projects against Gypsy-Travellers in the UK (Powell 2011); the power differentials between the Gypsies and the settled population in the UK and its relationship to stigmatization (Powell 2008); the struggle against Roma forced eviction seen as a need for revitalizing 'the uncanny' (Lancione 2017); the validity of the "myth of the placeless Gypsy" (Kabachnik 2010); the resistance of GypsyTravellers in the UK concerning the anti-nomadic legislation (Kabachnik 2014); the applicability of the Wacquant's concept of ghetto concerning the Gypsy-Travellers in the UK (Powell 2013); the effect of the economic crisis and austerity politics on the strategies of pro-Roma nongovernmental organisations (NGOs) and movements fighting for Roma access to housing in Rome (Italy) (Maestri 2014); the effects of post-socialist transformation in Eastern and Central Europe and the ways in which it has been lived through and reflected upon by the members of the Czech urban and Slovakian rural Roma (Gypsy) communities living in the urban ghettos and "Gypsy settlements" (Ruzicka 2012); and the adaptations of the Gypsies and the Travellers living in "bricks and mortar" accommodation and its effect on social segregation and 'parallel communities' (Greenfields and Smith 2010). However, the structured examination of inward and outward mechanisms connected to social capital and the social capital's role in the social mobility of the urban underclass Roma are missing in the current literature.

After identifying the potential significance of social capital concerning the social mobility of the underclass Roma and the related research gap, we address two questions within the present study:

What inward and outward mechanisms are connected to social capital in the case of the underclass urban Roma communities living in segregates (ghettos)?

What kind of interventions related to social capital are able to potentially play a role in enhancing mobility and alleviating poverty for the segregated urban underclass Roma?

\section{Methodology}

Our research was carried out in the major Hungarian city of Szeged, with approximately 160000 inhabitants. Here, about 400 people live in the two isolated Roma segregates. The smaller segregate has nearly 125 inhabitants living in 4 buildings (16 flats) and it is situated on the outskirts of the city. The larger segregate is located on a walking distance to the city center 
and it is almost double in size compared to the smaller one (Fig. 1). Both segregates correspond to the "ghetto" definition of Wacquant (2012) introduced in the previous section. In order to examine our research questions, two data collection methods were used. Both methods are grounded in a participatory action research (PAR) cooperation between the local underclass Roma, the local Roma representatives and the NGOs and local middle-class scholar-activists, which started in 2011. PAR "is a research paradigm within the social sciences

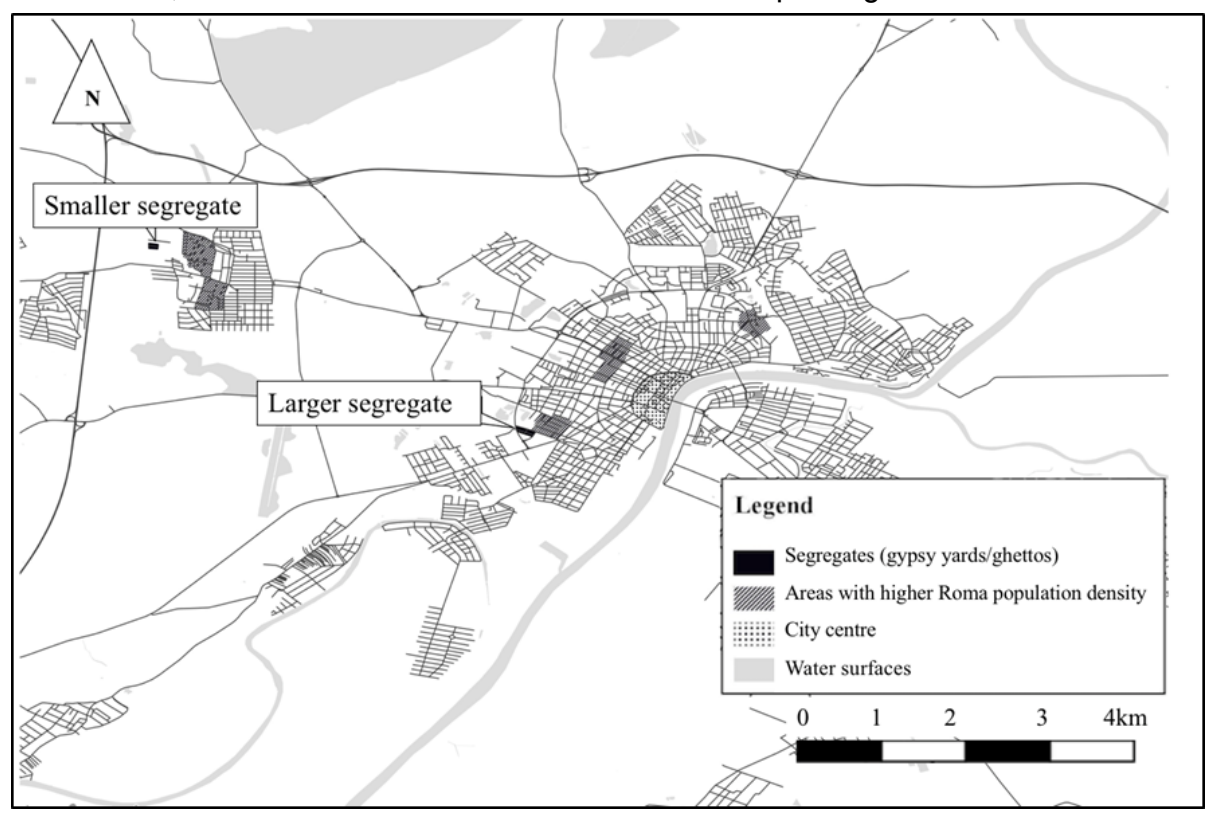

Fig. 1 - Study area: smaller and larger Roma segregates in Szeged Source: Shape file was created from OpenStreetMap data and it is licensed under the Open Database 1.0 License from: http://www.geofabrik.de/data/shapefiles.html

which emphasizes collaborative participation of trained researchers as well as local communities in producing knowledge directly relevant to the stakeholder community" (Coghlan and Brydon-Miller 2016: 583). PAR intends to contribute to social change besides contributing to the theoretical corpus of the social sciences. Therefore, PAR is a structured social research process being based on a continuous and long-term cooperation of researcher and nonresearcher participants and actions serving both to social change and to scientific observation and understanding.

Inside the present PAR process, Roma people have identified numerous problems to be dealt with during the past 6 years of cooperation, including the discrimination they face; extreme poverty and the lack of access to subsistence goods; poor and uncertain housing conditions (Fig. 2); the lack of legal, stable job opportunities; and the inability to provide perspectives for the future of their children (e.g. by helping them to succeed in school).

Within the present study, we rely on our observations related to one initiative within the broader PAR process: the patronage network. This network was initiated in 2014 within the broader PAR cooperation. The aim of the initiative is to create long-term personal, one-to-one connections between the local middle-class and the underclass Roma families mostly living in one of the segregates of the city. These connections then become rather heterogeneous: the only general pattern is that families cooperate and patron (middle class) families support the 


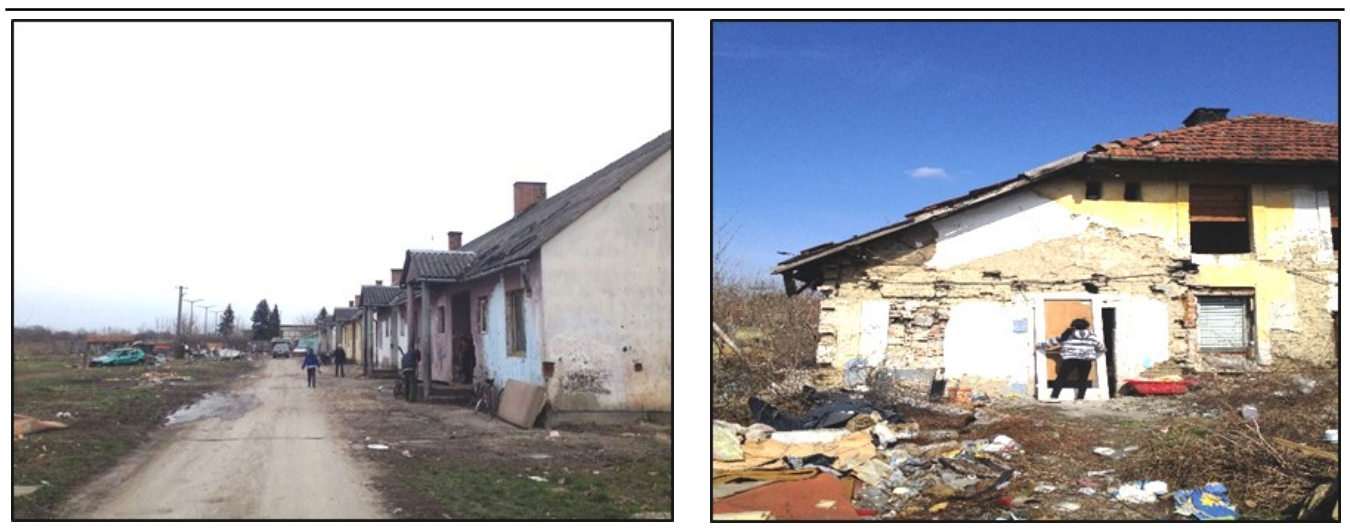

Fig. 2 - Housing conditions in smaller segregates (left) and larger segregates (right) Source: Janka Tóth (2017) and Méreiné Berki (2017)

patroned (underclass Roma) families concerning different issues in different ways, including recreation, educational and health issues, job search, etc. The initiative has built previously non -existent connections (bridges) between the local middleclass and underclass families. Such an initiative and related relationships between families of different social groups serve as extremely good objects of observation in the case the aim is to observe the interpersonal connections and connections between individuals and institutions (involved individuals/families often cooperate concerning the issues which involve cooperation with the social institutions, e.g. school issues, labor issues, housing issues, etc.). Thus, this initiative - and the broader PAR process - provides opportunities for observations concerning both bonding, linking and bridging social capital.

Two sources of data were used for the present analysis. First, three of the authors are involved in the patronage network (as patrons). These experiences are recorded in research diaries of scholar-activists. Besides this, 33 semi-structured qualitative interviews were conducted -27 with Roma people living in local segregates and 6 with members of the patronage network (patrons) (Table 1).

Using and building on PAR as a research approach is important for us in being able to meaningfully examine our research questions for several reasons. Action orientation means the recognition of expectations of non-researcher participants towards the process of cooperation (taking joint actions serving their interests instead of only having scientific observations which are only useful for researchers) plays a crucial role in building trust among participants (Arieli et al. 2009) and overcoming the general distrust of marginalized groups (including the marginalized Roma) towards social research (Munté et al. 2011). Our experience shows that common actions and related commitments are prerequisites of engaged and honest participation in the research for the marginalized groups. The topic of extreme poverty is an extremely sensitive area for research and the world of segregates (ghettos) is a closed world that is rather difficult to approach. Moreover, successful approaching does not here in itself mean reliable and valid research results because of the existence of distrust, divergence in norms of communication, inner social relations (hierarchies) of communities, etc. Honesty and engagement cannot be reached by applying conventional research methods involving one-time data collection (interaction) between researcher and lay participants (e.g. quantitative surveys or qualitative interviews) in an environment characterized by high social distance and lack of trust. Our observations clearly show that, for example, the application of conventional formal research standards (e.g. making notes during interviews, or simply using the expression of "interview" instead of simply saying "talking" or "chat") causes the underclass urban Roma to 
The Role of Social Capital and Interpersonal Relations in the Alleviation of Extreme Poverty and Spatial Segregation of Romani people in Szeged

Interviewees characteristics: age, gender, profession

Table 1

\begin{tabular}{|c|c|c|c|c|}
\hline No & Interviewees & $\begin{array}{l}\text { Age } \\
\text { (years } \\
\text { old) }\end{array}$ & Gender & $\begin{array}{l}\text { Profession } \\
\text { (Activity) }\end{array}$ \\
\hline & $\begin{array}{l}\text { Underclass Roma persons } \\
\text { living in the larger segregate }\end{array}$ & & & \\
\hline 1 & Interviewees no 1 and no 2 & 53 and 27 & 2 females & public workers \\
\hline 2 & Interviewee no 3 & 38 & Female & public worker \\
\hline 3 & Interviewee no 4 & 35 & Female & cleaning worker \\
\hline 4 & Interviewee no 5 & 50 & Female & unemployed \\
\hline 5 & Interviewee no 6 & 25 & Female & stay-at-home mom \\
\hline 6 & Interviewee no 7 & 40 & Female & cleaning worker \\
\hline 7 & Interviewees no 8 and no 9 & 24 and 40 & $\begin{array}{l}\text { female and } \\
\text { male }\end{array}$ & $\begin{array}{l}\text { stay-at-home mom; } \\
\text { unemployed }\end{array}$ \\
\hline 8 & Interviewee no 10 & 20 & Female & student \\
\hline 9 & Interviewee no 11 & 40 & Female & cleaning worker \\
\hline 10 & Interviewee no 12 & 23 & Female & public worker \\
\hline 11 & Interviewee no 13 & 61 & Female & pensioner \\
\hline 12 & Interviewee no 14 & 35 & Male & unemployed \\
\hline 13 & Interviewee no 15 & 46 & Female & unemployed \\
\hline \multirow[t]{2}{*}{14} & Interviewee no 16 & 50 & Female & unemployed \\
\hline & $\begin{array}{l}\text { Underclass Roma persons } \\
\text { living in the smaller segregate }\end{array}$ & & & \\
\hline 15 & Interviewees no 17 and no 18 & 33 and 33 & $\begin{array}{l}\text { female and } \\
\text { male }\end{array}$ & $\begin{array}{l}\text { stay-at-home mom; } \\
\text { unemployed }\end{array}$ \\
\hline 16 & Interviewee no 19 & 40 & Female & unemployed \\
\hline 17 & Interviewees no 20 and no 21 & 40 and 40 & 2 females & public workers \\
\hline 18 & Interviewee no 22 & 40 & Female & disability pensioner \\
\hline 19 & Interviewee no 23 & 23 & Male & unemployed \\
\hline 20 & Interviewee no 24 & 33 & Female & stay-at-home mom \\
\hline 21 & Interviewee no 25 & 35 & Female & public worker \\
\hline 22 & Interviewee no 26 & 18 & Female & student \\
\hline \multirow[t]{2}{*}{23} & Interviewee no 27 & 40 & Female & public worker \\
\hline & $\begin{array}{l}\text { Patrons belonging to local } \\
\text { middle class }\end{array}$ & & & \\
\hline 24 & Interviewee no 28 & 62 & Female & teacher \\
\hline 25 & Interviewee no 29 & 33 & Female & academic \\
\hline 26 & Interviewee no 30 & 37 & Male & academic \\
\hline 27 & Interviewee no 31 & 29 & Female & academic \\
\hline 28 & Interviewee no 32 & 56 & Male & retired police officer \\
\hline 29 & Interviewee no 33 & 41 & Female & academic \\
\hline
\end{tabular}

become alert and distrustful. Thus, we can say that trust (and PAR, which enables it in our case) is a prerequisite of being able to collect reliable and valid data in the context of our research.

The action-oriented involvement of scholar-activists who "do not split their work from their life" (Van der Meulen 2011: 370) also enables (1) having idiographic observations concerning the diverse spheres of life of the local Roma underclass and (2) the conventional "researcher vs. subjects" roles to be increasingly enriched by the peer perspective allowing all voices and (unconventional) viewpoints to be expressed and to address "undiscussables" (Bradbury and 
Reason 2003: 165).

PAR also provides opportunities for the long-term observations of dynamic phenomena which reveal themselves on interpersonal levels. Such phenomena cannot be meaningfully observed by applying "snapshot" observation methods involving one-time interaction and observation. Since the essence of social capital relates to dynamic interpersonal and inter-organizational connections (relationships, ties) between individuals and formal and informal social groups and the social effects of these connections, PAR provides an excellent approach (method) for observation here.

While cooperation, action orientation and engagement (as features of PAR) clearly appear as beneficial factors concerning data quality on the one hand, they are also challenging for researchers on the other hand. The "essential challenge in PAR is the unique combination of deep empathic and political involvement coupled with critical and reflective research, which expects the researcher to treat his or her own experiences at 'arm's length" (Levin 2012: 133134). Experts have a dual task here: they have to be able to combine empathy and involvement with critical and analytical skills. Our experiences show that engagement makes it more difficult to take the position of the "outsider" researcher. Being aware of this dual challenge, continuous self-reflection on researcher roles and influence was applied by researchers during data recording and analysis.

Qualitative content analysis (Titscher et al. 2000) was carried out along our research questions on our data sources (those parts of our research diaries which are related to the patronage program and interview transcripts). Researchers looked for those parts of these texts which were related to the presence of (or lack of) the coming into being (or disappearing) and functioning of bonding, linking and bridging social capital. Relationships with individuals, communities and formal and informal institutions were all considered. Relevant text was also analyzed according to whether ties identified are related to alienating or approximating mechanisms concerning the majority society. Researchers paid special attention to being "open" during the process of analysis: to also consider those parts of the text which are able to bring in new perspectives to the analysis beyond the analytical framework (and categories) derived from the theory of social capital. All interviews were analyzed by two researchers. Results were compared and discussed until agreement was reached. Each researcher analyzed their own research diaries and results were circulated within the research team and discussed until consensus was reached about the messages of research diaries (Table 2). Below we present our analysis enriched with quotations encoding typical positions related to identified codes and categories. Unless stated otherwise, quotations belong to local underclass Roma residents living in urban segregates. Our results are presented in a comparative way we always reflect on the differences we experienced between the examined segregates.

\section{Results and Discussion}

Tensions between bonding and bridging social capital

Our observations reinforce those research results (Stewart 2001, Albert and Dávid 2006, Farkas 2012) which found that the social network of Roma families living in segregates is rather closed. Inward ties within segregated communities are rather intense, especially that most underclass Roma living in the local segregates are also in affinity with many other inhabitants besides being neighbors - especially in the smaller segregate (Table 2 ).

The presence of bonding capital serves as a resource for those who possess it. It provides (1) material resources through reciprocity (including small loans, monetary support, food, medicines, electricity or internet) and (2) it contributes to non-material components of well- 
The Role of Social Capital and Interpersonal Relations in the Alleviation of Extreme Poverty and Spatial Segregation of Romani people in Szeged

Units of analysis and results

Table 2

\begin{tabular}{|c|c|c|c|}
\hline \multirow{2}{*}{ Units of analysis } & \multicolumn{2}{|c|}{ Results } \\
\cline { 2 - 3 } & & $\begin{array}{c}\text { Resource } \\
\text { Material resources through } \\
\text { reciprocity and enhanced non- } \\
\text { material components of well-being }\end{array}$ & Limits to social mobility \\
\cline { 2 - 3 } \begin{tabular}{c} 
Roma families \\
\cline { 2 - 3 }
\end{tabular} & $\begin{array}{c}\text { Material support and welfare } \\
\text { services by institutions }\end{array}$ & $\begin{array}{c}\text { Institutional anomalies, } \\
\text { distrust in formal } \\
\text { institutions }\end{array}$ \\
\cline { 2 - 4 } & & $\begin{array}{c}\text { Artificial bridging connections - } \\
\text { Patronage Network }\end{array}$ & $\begin{array}{c}\text { Lack of naturally } \\
\text { emerging bridging } \\
\text { connections }\end{array}$ \\
\hline Patrons and & $\begin{array}{c}\text { Social bridge through personal } \\
\text { relationships, personalized } \\
\text { resources, facilitation and mutual } \\
\text { understanding }\end{array}$ & $\begin{array}{c}\text { Divergent understanding } \\
\text { of efficiency }\end{array}$ \\
\hline
\end{tabular}

being (the presence of friends, a feeling of home, the presence of recreational activities, a safe place for children, child care). However, we do not intend to highlight the notion of "romantic" ghetto, where there are strong community and family ties. Clough Marinaro (2015) precisely demonstrated how, at least in the Italian context, Roma camps are better seen as neo-ghettos rather than ghetto, because the solidarity once present there has been undermined. Recent research in Hungary found that ties based on inner solidarity have become weaker during the past decade, and support for the segregated underclass Roma is rather provided by the weaker ties of bridging and linking capital. Even more, some of the extremely poor might live in a "vacuum of ties": they lack both strong inner and weak outward ties and therefore they are not able to convert any connections to resources (Solt 2010, Messing 2006, Messing and Molnár 2011) - clear signs of weakening supporting relationships also appear in our empirical results, especially in the case of the larger segregate.

Strong bonding ties also limit social mobility (Kemény et al. 2004). This involves (1) the lack of the private sphere and strong expectations of sharing, which limit the material development of families (people, households). A family living in the larger segregate serves as an expressive example of that. The family managed to buy a used car with the support of the patronage network. Immediately on the same day, numerous relatives and friends asked for their help in transportation (of people and goods). Such expectations meant a significant burden on the budget of the family. Such expectations are often sources of conflict because a basic selfdefense strategy for better-off families is to hide material development and not to share extra material resources. In case such "secrets" are revealed, they are often sanctioned by the community, most often in the form of vicious gossip. Thus, material development is either sanctioned with obligatory sharing or hostile attitudes. Social mobility is also limited by (2) "dangerous", "bad" (quotations resulted from interviewees no 2, 3, 5, 7, 9, 11, 12, 15-20, 22, 23) examples transmitted towards children on a daily basis of inhabitants living with addictions or earning their living from the grey economy or crime. As numerous parents often formulate it, "it is impossible to raise children in a normal way among such circumstances" (quote generally resulted from interviewees no $2,5,6,9,13,15,17,18,20,22,23$ ). Last but not least, (3) people often have no alternatives than accepting the strong and oppressive inner hierarchy of the segregate where they live because of strong, closed bonding ties, poverty and missing bridging ties (see the following section). An example of that is the phenomena of usury. Usurists - persons providing loans (the usury) characterized by high interest rates and monthly interest periods for the community members who have no chance of accessing legal loans (e.g. 
from private banks) - are generally very "strong" community members. Such loans - beside meaning extremely important resources - do not only mean extreme material burden for the affected families and strongly limited opportunities to break out from the debt trap (and poverty trap in general), but also cause that people having usury loans have no other chance but to accept oppression and injustices (e.g. the oppressive and unjust actions of the usurists) because of their dependent situation.

The above shows that although bonding social capital means a significant resource for the inhabitants of the segregated Roma communities on the one hand, it means a serious limiting factor concerning social mobility on the other hand. This contributes to the emergence of specific inner norms and rules which contribute to social integration (integration within the community), but it overwrites other rules and norms which are (would be) necessary for system integration (integration to the majority society) since this latter is based on the system of norms of the majority. Examples of such tensions between the norms of social integration and system integration, limiting material development (and social mobility) include two issues:

- $\quad$ strong community expectations of sharing described earlier (also called extreme egalitarianism by Ladányi and Szelényi 2004) or "feasts" (e.g. preparing a great amount of food, even if people are in a difficult financial situation and most of it will be wasted, when relatives come to visit); and

- $\quad$ behavior in the labor market such as when family members - three to five people - with a common employer often quit jobs together in cases when someone from the family quits or is fired in order to show their solidarity, "not to leave the other alone" (quotation presented by interviewee no 8), or when they do not attend their workplace for shorter periods (from one to several days) when there are family expectations towards help (e.g. when renovating homes).

While acting by the norms of the majority could play a role in social mobility in the long run, adaptation to the specific inner norms of segregated communities is a pledge of everyday survival for the underclass. The result is the tension between social and system integration, bonding and bridging ties (social capital). It is of small wonder that bonding ties (the need for everyday survival) often overwrite bridging ties (the long-term and uncertain benefits of social integration) in an environment characterized by daily hardships and continuous existential uncertainty.

\section{Missing bridging and linking connections}

The population of segregates is rather heterogeneous concerning their material well-being, resources, capabilities and social relations. While for certain families, social relations and resources are almost exclusively limited to the segregate and its community, others are materially better-off and more integrated into the majority society concerning both their resources and social ties. However, our observations reinforce those research results (Messing 2006) according to which the underclass Roma living in segregates mostly lack bridging connections - even in an urban environment. Despite this, bridging social capital means a significant resource when it exists - most of all for those families, which are already on their way to system integration. Our observations show that bridging connections most of all help in accessing (mostly unofficial) job opportunities - e.g. non-underclass, non-Roma acquaintances (ties) also help to overcome prejudices and lack of trust being present towards the (urban underclass) Roma in the labor market.

Connections to institutions are related to linking social capital. However, our observations show a high level of distrust towards formal social institutions in the case of the segregated underclass urban Roma. Trust between the segregated urban underclass Roma and the majority population is also a more general problem - see the following section. Numerous 
institutional anomalies contribute to this phenomenon. Such anomalies are school failure and school (and kindergarten) segregation concerning the educational institutions. The experiences of most underclass Roma parents, according to which Hungarian schools are most of all places of exclusion for the underclass Roma and they rather reinforce social disadvantages instead of compensating for these, are in line with the related special literature (a good review of this topic is provided in Hungarian by Fejes et al. 2013). The most distrusted social institution is the police. Most underclass Roma think that the police apply a double standard towards the underclass Roma living in segregates. This means overdone sanctioning:

- $\quad$ "They also fined me for 5000 forints because I carried my smaller sister on my bicycle. They did not tell me to stop and get off the bike and do not do it again but started to write the citation immediately. (...) They are extremely one-sided with the Roma" (quotation from interviewee no 1).

The underclass Roma's perspective also reinforce that segregates are also handled as beyond the pale areas (Harper et al. 2009) by the police:

- $\quad$ "They did not do anything. They say that these are only Gypsies, let them kill each other, we will at least have fewer problems after that" (quotation from interviewee no 14).

Beside the general distrust in official social institutions, positive experiences are also present. However, these are not related to (the functioning of) institutions themselves but to personal relationships with certain institutional representatives (e.g. a school director, certain workers of the local family support office or local district nurse). These relations are important forms of social capital for the underclass urban Roma, providing most of all enhanced access to the basic goods (including clothes) and help in administrative issues (connected to e.g. accessing social care) on the one hand, but often temporary and uncertain on the other hand - e.g. fluctuation within local institutions for the social support of the poor is rather high, workers are often changed several times a year.

\section{Creating meaningful links - lessons learned from the patronage program}

The patronage network is an initiative to create social ties which span social groups (see above). Ties created within this initiative cannot be univocally classified according the standard social tie categories (bridging-bonding-lining) of social capital. Relationships created by the patronage program are (1) bridging in the sense that these span social groups; (2) bonding in the sense that quite a few of these are rather strong ties ("we are like family members for each other" - quotation reiterated by interviewees no 20,21 and 30) as formulated by both patron and patroned families); and (3) linking in the sense that the initiative was begun and had been run by an informal network of people (as an institution) with the explicit goal of supporting the local Roma underclass.

Such a program provides a good opportunity for observing the functioning of both bonding, linking and bridging social capital; the effects of bonding and bridging interpersonal relations; and connections to social institutions. Such observations might help (1) to identify those points (stages) where poverty alleviation policies and measures through formal social institutions fail, and (2) to reveal those factors which pave the way to social mobility and poverty alleviation.

\section{Local resources}

The patronage network means significant resources for the underclass Roma participants. Material support is related to both family crises (e.g. lack of food or inability to pay bills) and investment in the future (e.g. being able to get rid of usury loans or support the concerning improvement of school performance of the underclass Roma children). Non-material support is 
just as important: the network secures mutual learning, help in complicated administrative issues or simply providing mental/spiritual support. Mutual learning between underclass and middle class families about each other's life worlds emerges "naturally" through cooperation e.g. by enhanced understanding and consciousness, but also in a more planned way: middle class families often help the underclass families to be able to better educate their children patrons often learn with underclass children to directly improve their school performance:

- $\quad$ "There is something happening to É. [a mother from the smaller segregate], she knows that there are people she can count on. This is the most important: there someone out there on who I can count on" (quotation from interviewee no 28).

Support here functions independently of large social systems for redistribution allowing for flexibly and personalization. This is of vital importance concerning social mobility and poverty alleviation because of the heterogeneity of the segregated urban underclass Roma concerning material well-being, resources, capabilities and social relations. While in some cases minor support (e.g. cooperation in preparing CVs or using the social connections of patron families) is enough for the underclass Roma families to integrate into the labor market (to get proper jobs), in other cases, access to the labor market is a far more difficult issue if possible at all (e.g. for those families where parents are illiterate, struggling with addictions, depression, etc.) and it requires active and initiating institutional support. It is clear that families in such enormously different situations need differentiated support sensitive to differences in family situations for social mobility, contrary to the standardized services provided by social institutions as observable in the examined context.

\section{Facilitation and representation}

It is often a difficulty for the supported underclass families to use the formal institutions properly. These institutions constitute a "middle class arena": communication skills, capabilities, knowledge, material background and self-lobbying capacity fitting the middle class norms and capabilities are needed for someone to use these in an efficient way. This also refers to those formal social institutions whose functions are related to the fulfillment of everyday basic needs, including education or healthcare. For example, arranging an appointment to a specialist in public healthcare often requires several phone calls, meaning an unaffordable problem for the extremely poor who do not have a phone or money to pay for outward calls. And, there exist numerous obstacles concerning the understanding and filling out of official forms in cases when someone is less educated, especially for those who are illiterate. Underclass urban Roma also often meet discrimination in official institutional arenas, which alienates them even more from being able to use these (Kabachnik 2014).

Interviewed patrons all emphasized that they function as facilitators between supported families and social institutions:

- $\quad$ We are like passports. We have an effect of raising trust between parties. I often feel myself as a facilitator between two worlds" (quotation from interviewee no 32).

Such institutions include education, health care, and the local public property (housing) company, but also firms (private institutions in the labor market). According to the perspective of patrons, supported families would fail more often concerning their relations with the social institutions without the support of patrons:

- $\quad$ Institutions are like that: they leave everyone behind who do not belong to their responsibility... I stepped up as someone who is able to represent their (patroned family) interest" (quotation from interviewee no 30).

Such facilitation and interest representation clearly help mobility (e.g. in school issues). A general experience of patrons is that schools are not able to properly communicate with the 
underclass Roma parents and they are often more cooperative towards the middle class patrons in cases when they appear as facilitators or representatives for these families. Reasons for improper communication include: (1) general prejudices and discrimination against the Roma (Harper et al. 2009, Kabachnik 2014) also characteristic to certain institutional representatives; (2) self-understanding of tasks and roles ("beyond my task" attitude) of institutions themselves and employees; (3) lack of resources (e.g. underclass Roma parents are not accessible through phones and institutions do not have resources to carry out more demanding communication channels - e.g. family visits); and (4) divergence in norms of communication (e.g. numerous underclass parents often simply do not understand bureaucratic language applied by the social institution, including schools).

\section{Mutual understanding}

We all tend to generalize and are capable of having prejudices in our relations to people and social groups which are different from us. According to our observations, becoming a patron starting to support poor Roma families facing extreme prejudices - demands open and emphatic thinking and attitudes. However, patrons still often face their prejudices during their cooperation with the underclass Roma. Realizing this issue, together with a long-term commitment (feelings of love, friendship, caring and responsibility, as emphasized by both patron and patroned families), provides patrons with continuous motivation to reflect on their prejudices:

- $\quad$ "I experienced it myself, that however enlightened I consider myself, I also have my prejudices. But such prejudices are continuously left behind in such a situation" (quotation from interviewee no 31).

- $\quad$ "Our prejudices have become groundless, because if you understand what is happening and why, then your perspective changes" (quotation from interviewee no 29).

Bridging connections means that different life worlds meet. Cooperation creates a situation where the understanding and appreciation of each other's situation and behavior is starting to happen:

- $\quad$ Now I understand it better what a poverty trap means. It is not like you read about it and then know it. It is a situation characterized by extreme inertia" (quotation from interviewee no 32).

Such understanding and appreciation is mutual. Middle class and underclass actors continuously reevaluate their presumptions:

- "I wrote it here, that Hungarians are forbidden to enter. But you are allowed to enter". "In cases when someone goes with them [the underclass Roma] she continuously experiences those looks and reactions, which she has not experienced before. You also become a Gypsy for that period" (quotation from interviewee no 33).

\section{Questions of efficiency}

Participants of the patronage network often experience that their measures and judgements concerning efficiency are often divergent. Even though most patrons are rather critical (skeptical) towards the existing social structures which are often organized by technocratic and neoliberal values and function in an inhuman way, they still consider most of all enhanced system integration as progress:

- "I wrote her a CV. Now she managed to get a job. I consider it a huge success" (quotation from interviewee no 29).

Meanwhile, the underclass Roma often value support related to the management of family crises as more important than long term "investments" - also called as "present orientation" by 
some (Loewenstein 1985, Ladányi and Szelényi 2004, Romeo 2005):

- $\quad$ "They spend most of their days with trying to solve their everyday problems. Meanwhile I want kids to have some education" (quotation from interviewee no 28).

Connections between patron and patroned families seem to be able to approximate these diverging expectations. Middle class patrons are often able to understand the reasons behind present orientation through long-term and intense cooperation, and they also experience changes in the attitudes of supported families. The best example of that are the attitudes towards learning in the official school system. School is often an area of lack of success and exclusion for the underclass Roma, where "we always sat at the last row, separated from the others", and the same used to apply to parents when they were of school age. Thus, knowledge acquired through schooling does not play a vital role in the subsistence strategies for the underclass Roma. Discrimination, exclusion and the lack of perceived importance of knowledge have significant consequences. Although most underclass Roma families emphasize that education is vital in providing their children perspectives for the future, e.g. by acquiring a profession, former experiences together with the lack of capabilities (e.g. analphabetism) and extreme poverty (problems with fulfilling subsistence needs on a daily basis), result in that, when it comes to actual actions, school and education of children are not among top priorities (Fejes et al. 2013). Patroning ties seem to be able to approximate (change) these priorities in a pro-education direction, and thus open up spaces for the enhanced mobility of the underclass participants:

- $\quad$ "They did not attend school last year at all. Then [children] they passed the re-take exam, which seldom happens. They did not think that they can make it". "She is more interested in learning now. M. (the patron) has such an effect on her". "He would like to raise their children in a different way, because he understands how important learning is" (quotation from interviewee no 30).

\section{Conclusions}

Observing an initiative aimed at creating social ties which span social groups in the approach of PAR provided us an opportunity to examine the dynamics of social relations on an interpersonal level for a longer period of time. Although both the reliability and validity of our analysis are limited by the fact that changes related to social capital appear on the long run (many years or even decades), our analysis being mostly related to a "fresh" (two-and-a-halfyear-old) initiative, our observations still provide us interesting insights about the role of the social capital in social mobility and in alleviating poverty for the segregated urban underclass Roma. By observing the functioning of bonding, linking and bridging social capital, numerous points (stages) where poverty alleviation through formal social institutions fail and factors potentially paving the way to social mobility and poverty alleviation were identified.

Examining the inward and outward ties of two segregated urban underclass Roma communities showed that tensions might emerge between the bonding and bridging ties (social and system integration) in the cases where initiatives (e.g. anti-segregation policies) and social institutions are not responsive to the functioning and significance of bonding relations for the urban underclass Roma.

Strong bonding ties and social integration do not only mean the "natural milieu" for community members but also substantial material and non-material resources for day-to-day survival. Measures and institutions not taking this into account might lead to situations where social integration (bonding ties) will overwrite initiatives for system integration. System integration among such circumstances might mean being "forced" into hostile (discriminatory) environments with long-term and uncertain (or no) benefits for the discriminated and marginalized groups. Thus, measures and institutions for poverty alleviation and social mobility 
which only focus on system integration and are not sensitive to the natural ties and milieu of the marginalized might lead to situations where the rift between the middle class and the underclass becomes even deeper. Meanwhile, naturally emerging bridging relationships are rare and hardly mean any resources for the urban underclass Roma, especially concerning system integration.

Our observations show that regular, long-term interpersonal relationships between the middle class and the underclass Roma are able to initiate changes in numerous areas through securing personalized resources, facilitation and mutual understanding. These observations carry important messages concerning the functioning of linking social capital. At the present, linking capital is not performing according to its planned function in the context under analysis: people do not trust social institutions which are more or less unable to contribute to poverty alleviation and social mobility for the underclass urban Roma. Rethinking the rigidity of social institutions, which are vital for social mobility, would be of essential importance here. Institutions should be made more "personal" and provide more "personalized" services which reflect both on the diversity of the urban underclass Roma families and on their life worlds: (1) more flexible material and non-material support concerning short term needs and investment in the future; (2) stepping out of purely middle class tools (resources) and norms of communication; (3) recognizing and fighting negligence, prejudices and discrimination within the society in general and the social institutions; and (4) acknowledging that the value of social integration, bonding ties and related norms of the underclass might all lead to enhanced understanding and (more trusted) relationships between the social institutions and the urban underclass - a better quality of linking social capital for social mobility and poverty alleviation.

Thus, our results show that (1) more personal, personalized and sensible, and (2) less standardized solutions are needed for linking social capital to better serve social mobility and poverty alleviation. This leads us to the dilemma of standardization vs. personalization. Standardized institutions are more rigid and thus not only offer less room for flexibility and personalization but also for autocracy. Thus, the personalization of social institutions might mean less rigidity and more room for flexibility and personalization on the one hand, but also for autocracy on the other hand. How to plan linking social capital for social mobility and poverty alleviation in a way that it is both flexible and personalized and resist autocracy, is a vital question open for further research where action research also has a great amount of potential to offer (Bradbury and Reason 2003).

\section{Acknowledgements}

We are grateful to all our Roma and patron participants in the PAR project and to Gyula Nagy for helping us with providing suggestions on the map of this paper.

\section{References}

ALBERT F., DÁVID B. (2006), A kapcsolati tőke dimenziói etnikai metszetben (Dimensions of social capital - an ethnic approach), in: Kolosi T., Tóth I. G., Vukovich G. (eds.), Társadalmi riport, Tárki, Budapest, pp. 351-369.

ANDRIANI L., KARYAMPAS D. (2015), Social capital, poverty and social exclusion in Italy, Revista Debates 9 (2), 77-113.

ARCHER M. (1996), Social integration and system integration: developing the distinction, Sociology 30 (4), 679-699.

ARIELI D., FRIEDMAN V. J., AGBARIA K. (2009), The paradox of participation in action research, Action Research 7 (3), 263-290.

BAIYEGUNHI L. J. S. (2014), Social capital effects on rural household poverty in Msinga, KwaZulu-Natal, South Africa, Agrekon 53 (2), 47-64. 
BEN-PORATH Y. (1980), The f-connection: families, friends, and firms and the organization of exchange, Population and Development Review 6 (1), 1-30.

BOON B., FARNSWORTH J. (2011), Social exclusion and poverty: translating social capital into accessible resources, Social Policy and Administration 45 (5), 507-524.

BOURDIEU P. (1986), Gazdasági töke, kulturális tőke, társadalmi tőke (Economic capital, cultural capital, social capital), in: Angelusz R. (ed.), A társadalmi rétegződés komponensei (Components of social stratification), Új Mandátum, Budapest, pp. 138-155.

BRADBURY H., REASON P. (2003), Action research: an opportunity for revitalizing research purpose and practices, Qualitative Social Work 2 (2), 155-175.

CASTEL R. (2000), The roads to disaffiliation: insecure work and vulnerable relationships, International Journal of Urban and Regional Research 24 (3), 519-535.

CLOUGH MARINARO I. (2015), The rise of Italy's neo-ghettos, Journal of Urban History 41 (3), 368-387.

COGHLAN D., BRYDON-MILLER M. (2016), The SAGE encyclopedia of action research, SAGE, London.

COLEMAN J. S. (1998), A társadalmi tőke az emberi tőke termelésében (Social capital in the production of human capital), in: Lengyel G., Szántó Z. (eds.), Tőkefajták: A társadalmi és kulturális erőforrások szociológiája (Types of capital: Sociology of social and cultural resources), Aula, Budapest, pp. 11-44.

CRETAN R., TURNOCK D. (2008), Romania's Roma population: from marginality to social integration, Scottish Geographical Journal 124 (4), 274-299.

CSIZMADIA Z. (2015), A kapcsolati tőke osztályszerkezeti aspektusai lokális metszetben (Class-system aspects of relational capital in a local approach), Századvég 78 (4), 49-75.

DAS R. J. (2004), Social capital and poverty of the wage-labour class: problems with the social capital theory, Transactions of the Institute of British Geographers 29 (1), 27-45.

DÜRKHEIM E. (1893), The division of labor in society, Free Press, New York.

ESSER H. (2008), The two meanings of social capital, in: Castiglione D., Van Deth J. W., Wolleb G. (eds.), The Handbook of Social Capital, Oxford University Press, Oxford, pp. 2249.

FARKAS Z. (2012), Hidak és sorompók. A telepfelszámolásban, a településeken végzett terepmunka tapasztalatai és integrációs hatásai (Bridges and barriers. Experiences and integrational effects of fieldwork related to anti-segregation), Társadalmi együttélés 4, 1-21.

FEHÉR K., VIRÁG T. (2014), Élet egy kisváros peremén (Living at the edge of a smal town), Tér és társadalom 28 (3), 50-65.

FEJES J. B., KELEMEN V., SZÜCS N. (2013), Szülõk mentorálása a hátrányos helyzet átörökitésének megelõzése érdekében (Mentoring parents in order to prevent the transmission of social disadvantages), SZTE JGYPK, Szeged.

FÜZÉR K. (2015), A bizalom társadalomelmélete és a társadalmi tőke szociológielmélete (The social theory of trust and the sociologic theory of social capital), Századvég (Társadalmi tőke különszám) 78 (4), 5-18.

FÜZER K., GERŐ M., SíK E., ZONGOR G. (2005), A társadalmi tőke növekedésének lehetőségei fejlesztéspolitikai eszközökkel (Opportunities for increasing the level of social capital by applying development policy tools), TÁRKI, Budapest.

GITTEL R., VIDAL A. (1998), Community organizing: building social capital as a development strategy, SAGE, London.

GRANOVETTER M. S. (1973), The strength of weak ties, American Journal of Sociology 78 (6), 1360-1380.

GREENBAUM S., HATHAWAY W., RODRIGUEZ C., SPALDING A., WARD B. (2008), Deconcentration and social capital: contradictions of a poverty alleviation policy, Journal of Poverty 12 (2), 201-228.

GREENFIELDS M., SMITH D. M. (2010), Housed Gypsy Travellers, social segregation and the reconstruction of communities, Housing Studies 25 (3), 397-412.

HANIFAN L. J. (1916), The rural school community center, The Annals of the American 
Academy of Political and Social Science 67, 130-138.

HARPER K., STEGER T., FILCAK R. (2009), Environmental justice and Roma communities in Central and Eastern Europe, Environmental Policy and Governance 19 (4), 251 -268 .

HAWKINS R. L., MAURER K. (2010), Bonding, bridging and linking: how social capital operated in New Orleans following Hurricane Katrina, British Journal of Social Work 40, 17771793.

KABACHNIK P. (2010), England or Uruguay? The persistence of place and the myth of the placeless Gypsy, Area 42 (2), 198-207.

KABACHNIK P. (2014), "Where can we put our homes?" Gypsies and Travelers in the English Green Belt, Journal of Cultural Geography 31 (3), 280-303.

KEMÉNY I., JANKY B., LENGYEL G. (2004), A magyarországi cigányság, 1971-2003 (Gypsies in Hungary, 1971-2003), Gondolat, Budapest.

KHATUN F., HASAN M. (2015), Social capital in microfinance: a critical investigation of Bangladesh, Journal of Emerging Trends in Economics and Management Sciences 6 (5), 315323.

LADÁNYI J. (2007), Az antiszegregációs programok szükségességéröl és lehetöségeiröl (On the necessity and possibilities of antisegregation programs), Kritika 36 (10), 2-4.

LADÁNYI J., SZELÉNYI I. (2004), A kirekesztettség változó formái (Changing forms of exclusion), Napvilág Kiadó, Budapest.

LANCIONE M. (2017), Revitalising the uncanny: challenging inertia in the struggle against forced evictions, Environment and Planning D: Society and Space, DOI: https:// doi.org/10.1177/0263775817701731.

LEVIN M. (2012), Academic integrity in action research, Action Research 10 (2), 133 149.

LOCKWOOD D. (1964), Social integration and system integration, in: Zollschan G. K., Hirsh W. (eds.), Explorations in Social Change, Houghton Mifflin, Boston.

LOEWENSTEIN G. (1985), The new underclass: a contemporary sociological dilemma, The Sociological Quarterly 26 (1), 35-48.

MAESTRI G. (2014), The economic crisis as opportunity: how austerity generates new strategies and solidarities for negotiating Roma access to housing in Rome, City 18 (6), 808823.

MÉREINÉ BERKI B., MÁLOVICS G., JUHÁSZ J. (2017), A hazai antiszegregációs tervek értékelése Amartya Sen képességszemlélete alapján (Evaluating Hungarian antisegregation plan based on Amartya Sen's capability approach), in: Bajmócy Z., Gébert J., Málovics G. (eds.), Helyi gazdaságfejlesztés a képességszemlélet alapján, JATEPress, Szeged, pp. 137-160.

MESSING V., MOLNÁR, E. (2011), Bezáródó kapcsolati hálók: szegény roma háztartások kapcsolati jellemzői (Networks of connections in the process of closure: characteristics of the social connections of poor Roma households), Esély 5, 47-74.

MESSING V. (2006), Lyukakból szőtt háló: háztartások közötti támogató kapcsolatok roma és nem roma szegények körében (A net wrapped of holes: supportive relationships among households in case of Roma and non-Roma poor people), Szociológiai Szemle 2, 3754.

MUNTÉ A., SERRADELL O., SORDÉ T. (2011), From research to policy: Roma participation through communicative organization, Qualitative Inquiry 17 (3), 256-266.

NFGM (2012), Városfejlesztési Kézikönyv. Második, javított kiadás (City Develepment Handbook. Second, Corrected Edition), Nemzeti Fejlesztési és Gazdasági Minisztérium, Retrieved from: www.terport.hu.

POWELL R. (2008), Understanding the stigmatization of Gypsies: power and the dialectics of (dis)identification, Housing, Theory and Society 25 (2), 87-109.

POWELL R. (2011), Gypsy-Travellers and welfare professional discourse: on individualization and social integration, Antipode 43 (2), 471-493. 
POWELL R. (2013), Loïc Wacquant's 'ghetto' and ethnic minority segregation in the UK: the neglected case of Gypsy-Travellers, International Journal of Urban and Regional Research 37 (1), 115-134.

PRETTY J. (2003), Social capital and the collective management of resources, Science 302 (5652), 1912-1914.

PUTNAM R. D. (1993), Making democracy work: civic traditions in modern Italy, Princeton University Press, Princeton.

PUTNAM R. D. (1995), Bowling alone: America's declining social capital, Journal of Democracy 6 (1), 65-78.

ROMEO J. H. (2005), Down and out in New York City: a participant-observation study of the poor and marginalized, Journal of Cultural Diversity 12 (4), 152-160.

RUZICKA M. (2012), Continuity or rupture? Roma/Gypsy communities in rural and urban environments under post-socialism, Journal of Rural Studies 28 (2), 81-88.

SAVANYA P. (2013), A társadalmi tőke jelentősége a gazdaságban, szerepe az innovációk társadalmi megformálásában (The role of social capital in economics and in the social formulation of innovation), in: Bajmócy Z., Elekes Z. (eds.), Innováció: a vállalati stratégiától a társadalmi stratégiáig, JATEPress, Szeged, pp. 140-149.

SCHVAB A. (2016), The area of influence of Baia Mare Municipality. Adaptation processes to a changing economy (in Romanian), Ars Docendi, Bucharest.

SCHVAB A., SîRODOEV I., PARASCHIV M., VĂIDIANU N. (2015), Steps in understanding the role of instability upon urban territorial systems, Journal of Urban and Regional Analysis 7 (2), 193-207.

SOLT Á. (2010), Élet a reményen túl. A szegregált telepen élök mentalitásvizsgálatának összegzése (Life beyond hope. Summary of the examination of mentality of people living in gypsy segregates), Szociológiai Szemle 20 (3), 100-133.

STEWART M. S. (2001), Depriváció, romák és az "underclass" (Deprivation, Roma and the underclass), Beszélö 7-8, 82-94.

TENZIN G., OTSUKA K., NATSUDA K. (2015), Can social capital reduce poverty? A study of rural households in Eastern Bhutan, Asian Economic Journal 29 (3), 243-264.

TITSCHER S., MEYER M., WODAK R., VETTER E. (2000), Methods of text and discourse analysis, SAGE, London.

VAN BAAR H. (2015), The Perpetual Mobile Machine of Forced Mobility: Europe's Roma and the Institutionalization of Rootlessness, in: Jansen J., Celikates R., de Bloois J. (eds.), The Irregularization of Migration in Contemporary Europe: detention, deportation, drowning, Rowman \& Littlefield International, New York and London, pp. 71-86.

VAN DER MEULEN E. (2011), Action research with sex workers: dismantling barriers and building bridges, Action Research 9 (4), 370-384.

WACQUANT L. (2012), A Janus-Faced Institution of Ethnoracial Closure: A Sociological Specification of the Ghetto, in: Hutchinson R., Haynes B. D. (eds.), The Ghetto. Contemporary Global Issues and Controversies, Westview Press, Boulder, pp. 1-32.

WOOLCOCK M., NARAYAN D. (2000), Social capital: implications for development theory, research and policy, World Bank Research Observer 15 (2), 225-249.

ZHANG Y., ZHOU X., LEI W. (2017), Social capital and its contingent value in poverty reduction: evidence from Western China, World Department 93, 350-361.

Initial submission: 07.09.2016

Revised submission: 12.05.2017

Final acceptance: 08.06.2017

Correspondence: Faculty of Economics and Business Administration, Research Centre, University of Szeged, Kálvária sgt. 1, 6722, Szeged, Hungary.

Email: malovics.gyorgy@eco.u-szeged.hu 